\title{
ON MATHEMATICAL DESCRIPTIONS OF UNCERTAIN PARAMETERS IN ENGINEERING STRUCTURES
}

\section{J. PELCZYŃSKI ${ }^{1}$}

Civil engineering is one of the many fields of occurrences of uncertain parameters. The present paper in an attempt to present and describe the most common methods used for inclusions of uncertain parameters. These methods can be applied in the area of civil engineering as well as for a larger domain. Definitions and short explanations of methods based on probability, interval analysis, fuzzy sets, and convex sets are presented. Selected advantages, disadvantages, and the most common fields of implementation are indicated.

An example of a cantilever beam presented in this paper shows the main differences between the methods. Results of the performed analysis indicate that the use of convex sets allows us to obtain an accuracy of results similar to stochastic models. At the same time, the computational speed characteristic for interval methods is maintained.

Keywords: uncertainty, convex set, interval, probability, fuzzy set

\section{INTRODUCTION}

Automation of production and control processes used nowadays has significant influence on the quality and precision of structural element manufacturing. However, the complete elimination of

\footnotetext{
${ }^{1}$ MSc., Eng., Warsaw University of Technology, Faculty of Civil Engineering, Ul Lecha Kaczyńskiego 16, 00-637 Warsaw, Poland, e-mail: j.pelczynski@il.pw.edu.pl
} 
uncertainty is not possible. Homogeneous materials do not exist in nature, though usually engineers and researchers make such an assumption.

Concrete as a mixture of different aggregate fractures and cement is not homogeneous by definition. Its mechanical properties are influenced by the composition of the mixture. Various batches of concrete delivered to the site may vary in content. During transport, the mixture may be exposed to a variety of temperatures, which can lead to a change of moisture content due to evaporation.

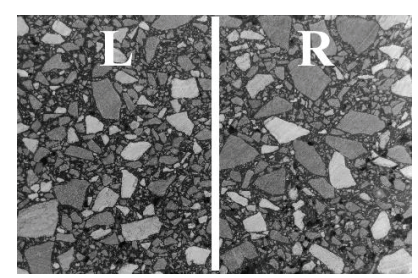

Fig. 1. Non-uniformly distributed aggregates in asphalt mixture. One can see a significant difference between the left and right side of the figure. From the author's own collections.

In addition, it is not possible to uniformly compact the concrete mix. As a result, the properties of the concrete can vary depending on location and time of built-in.

Asphalt, similarly to concrete, is also a mixture, but it consists of aggregate and binder. It is natural that the individual components are not uniformly distributed in the mixture (see Fig. 1). Due to the properties of the bitumen, the mechanical properties of the asphalt mixture are affected significantly by ambient temperature [32]. During the cold months the pavement becomes rigid - the exemplary asphalt mixture modulus for the wearing course according to Huang [25] is about $12.9 \mathrm{GPa}$ at $13.3{ }^{\circ} \mathrm{C}$ - while at $27.2^{\circ} \mathrm{C}$ the modulus is nearly ten times smaller. In timber, both solid and glued laminated, one can find knots, shakes, and checks which change local properties (see Fig. 2). Likewise, the moisture content has a significant influence on material behaviour. According to Ross [51] wood density can, for example, vary between $300 \mathrm{~kg} / \mathrm{m}^{3}$ for $0 \%$ moisture content and $750 \mathrm{~kg} / \mathrm{m}^{3}$ for $150 \%$ moisture content. Similarly, Young's modulus for Sitka spruce equals $39 \mathrm{MPa}$ for undried wood and $70 \mathrm{MPa}$ for wood with a $12 \%$ moisture content. 
Steel structures are very susceptible to corrosion, which changes element dimensions. This may result in a reduction of cross-section areas. Moreover, it is worth mentioning not only in regard to steel structures, the values of strength, modulus, etc. given in the Eurocodes are obtained experimentally. Usually, the designer is assured that no more than $5 \%$ of the specimens are characterized by lesser values. Last, but not least, is the fact that steel in microstructures is also heterogeneous, which can be seen in Fig. 3 [55].

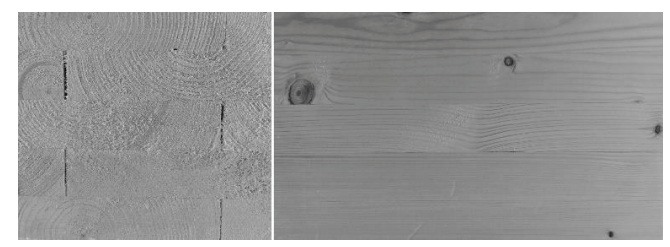

Fig. 2. Glued laminated timber with gaps and knots. From the author's own collections.

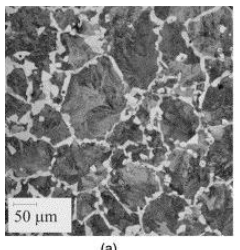

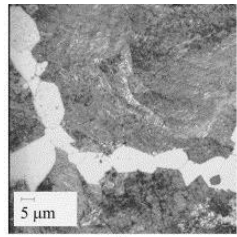

(b)

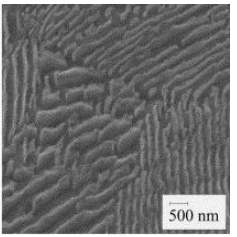

(c)

Fig. 3. Microstructure of steel [55].

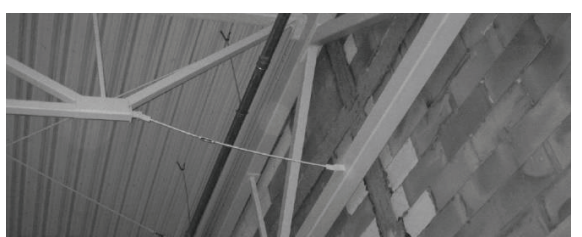

Fig. 4. Overextended strut due to improper prestress [29].

Furthermore, many structural elements are produced in situ or delivered in a form intended for further processing (concrete mix). Even the best measurement equipment used on construction sites has a certain accuracy, which, in conjunction with the built-in-element's imperfections, may affect the behaviour of the structure (see Fig. 4). Additional changes occurring during the structure's lifespan, such as foundation displacement, shrinkage, or creep, are also not possible to eliminate. 
In existing structures, both historical and contemporary, the necessity of expertise to assess the possibility of further use or execution of the designed changes is often required. In such cases, the lack of knowledge about the previously used materials or the fact that it was known but changed over time generates uncertain factors. It can be illustrated via an example of an analysis of a historic tenement where the authors had to determine the possible range of mechanical parameters of the masonry wall basing their calculations on existing literature [58].

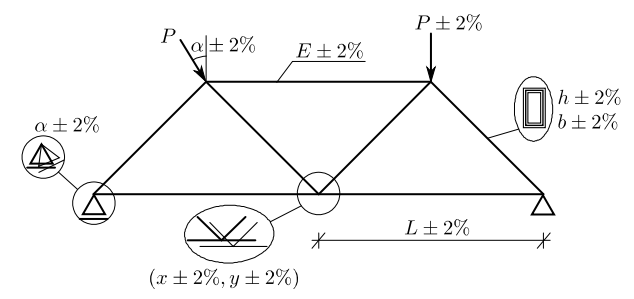

Fig. 5. Some possible uncertain parameters in truss.

In an example of an idealized plane truss (see Fig. 5) the variety of uncertain parameter groups occurring in the engineering structures mentioned above is presented symbolically.

The wide variety of uncertainties existing in these engineering structures implies a range of methods for their inclusion. In world literature, many publications dealing with the problem of introducing uncertainties can be found. The most common test methods are based on stochastic processes, interval arithmetic, fuzzy sets, and the use of convex set properties. One can also specify publications presenting mixed approaches. In stochastic methods, of which the Monte-Carlo simulation is the most popular, uncertain parameters are treated as random values and interval methods are based on interval analysis. It is assumed that the uncertain parameters are bonded from both above and below. The methods are fast, but incompetent use can lead to gross overestimations. Some generalization of interval analysis is achieved through the use of fuzzy sets. It allows us to determine to what extent a given element belongs to a set. Convex analysis is based on the assumption that some processes occurring in civil engineering can be described by convex sets.

In the following sections, the approaches mentioned above are described. The main advantages and disadvantages are presented and the most common fields of the application are indicated. In section 6 , a short example is presented. It presents a practical application of some of the described methods. 


\section{RANDOM METHODS}

According to Moens and Vandepitte [33], the stochastic approach can be denoted as the most valuable if three conditions are simultaneously present: reliable probabilistic data is available; a probabilistic description of the simulated non-deterministic behaviour is desired; and the available hardware and software is powerful enough to perform a sufficiently large number of simulations.

The probabilistic distribution (see Fig. 6) needed for proper process description is obtainable through experiments. However, the values are often a result of some assumptions due to the lack of experimental

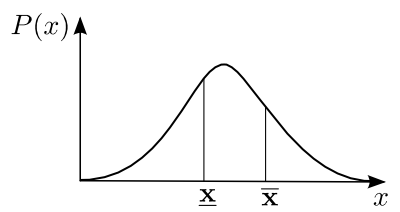

Fig. 6. Possibility distribution of $x$ lying in interval $[\underline{\mathbf{x}}, \overline{\mathbf{x}}]$.

data [60]. Likewise, according to Ekeland [14], randomness appears in situations when accurate but incomplete data is available. This statement, although originally referring to astronomical phenomena, is fully applicable in terms of engineering structures.

Dessombz, Thouverez, et al. [13] write that uncertain parameters are usually treated as random values. After Ghanem and Spanos [21] they write that many possible application methods in an engineering approach exist. The following deserve attention: the perturbation method, based on a series expansion of the stiffness matrix with respect to uncertain parameters by means of the Taylor expansion [30]; Neumann's extension method, in which a matrix reverse to the stiffness matrix is subject to series expansion [48, 54, 65], or the best known and most popular Monte-Carlo simulation (MCS).

The MCS popularity stems from the simplicity of implementation and the fact that it statistically converges to a proper result [42]. The latter is related to a significant disadvantage referring to all stochastic methods. Obtaining a satisfactory result is possible when a sufficient number of iterations is performed, which can be limited by hardware capabilities. MCS is commonly used in literature as a reference method [13]. Wider applications are presented in [63]. It is also often used for determination of safety factors in Load and Resistance Factor Design (LRFD) or the damage probability what is significant in terms of engineering structures design [2, 31]. Design codes known as Eurocodes (for example [18, 19]), obligatory in most European countries, are based on the LRFD method. It is a semi-probabilistic safety concept and is based on the theory of probability and partial 
safety factors. Corliss, Foley, et al. [11] describe the LRFD and underline that a solution obtained with MCS is subjected to a number of simulation-dependent errors.

Stefanou [60] proposes two categories of stochastic processes according to the type of probabilistic distribution: Gaussian and non-Gaussian. The author underlines that most uncertain parameters, like material, geometric properties, wind, or seismic load have a non-Gaussian distribution. Therefore, due to a lack of accurate information, for simplification purposes the Gauss assumption is often used. However, the subject of non-Gaussian distribution process simulation is frequently discussed [7, 28, 44].

Global literature has coined the concept of the stochastic finite element method (SFEM). One of its first formulations is publication [8]. SFEM generalizes the standard FEM approach by considering those finite elements whose properties are described by random values [54, 59, 62]. In literature one can find two main varieties: the perturbation approach and spectral SFEM. A detailed description is presented e.g. in [60]. SFEM is sometimes used in conjunction with MCS [20]. According to Papadrakakis and Papadopoulos [42], this combination is the only one that gives the opportunity to solve problems which include random variables, non-linearities, dynamic loading, and stability issues.

Bayesian statistics [6] provide alternative reasoning to the conventional probabilistic methods. Analysis based on Bayesian statistics assumes an initial distribution which describes prior knowledge about the uncertain parameters. This, along with the combination of the likelihood of the data (taken from observations, measurements, etc.), leads to the posterior distribution. Bayesian statistics are becoming more and more useful in the context of civil engineering problems [10, 66].

\section{INTERVAL METHODS}

According to Kearfott [27], the present development of interval analysis starts with the Moore dissertation [35]. Elishakoff, Duan, et al. [17] write that the idea of usage of interval arithmetic for an uncertainty calculation appears for the first time in [16]. An interval number (see Fig. 7) is defined as $\mathbf{a}=[\underline{\mathbf{a}}, \overline{\mathbf{a}}]=\{x \in \mathbb{R}: \underline{\mathbf{a}} \leqslant x \leqslant \overline{\mathbf{a}}\}$, meaning that interval arithmetic assumes that uncertain variables are treated as unknown, but bounded [57]. A description and the algorithms of the basic operations (addition, subtraction, multiplication, and division) - which naturally differ from operations defined for real numbers - can be found in [24]. 
The main advantage of the interval approach is the relatively high computing speed. However, incompetent use can cause large overestimations, which is a significant disadvantage. This can be illustrated by the following example (partially described in [34]).

Let's define a function as $f: D \subseteq \mathbb{R} \rightarrow \mathbb{R}$ given by the formula:

$$
f(x)=x(x-1)
$$

and assume that $x$ varies in interval $\mathbf{x}=[0,1] \subset D$. It is known that the tightest bound - the codomain of parabola $f(x)$ in range $[0,1]-$ is given by interval $[-0.25,0]$. However, if $x$ is replaced with $\mathbf{x}$ in Eq. (3.1) and algebraic operations consistent with the interval theory are made, the obtained result is $[-1,0]$.

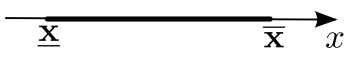

Fig. 7. Interval $[\underline{\mathbf{x}}, \overline{\mathbf{x}}]$.

Smith, Garloff, et al. [57] draw attention to the fact that some relations true in $\mathbb{R}$ are not correct according to the interval numbers. As an example they indicate a distributive law which now has a weak form of $\mathbf{a} \cdot(\mathbf{b}+\mathbf{c}) \subseteq \mathbf{a b}+\mathbf{a c}$. This relation can have a significant impact on the solution, which can be seen after converting function $f$ to $f(x)=x^{2}-x$ and calculating the result, which is $f(\mathbf{x})=[-1,1]$.

Moore [35] also indicates that the use of a union of intervals with smaller diameters can tighten the bound. Thus, if $\mathbf{x}=[0,0.5] \cup[0.5,1]$, the obtained result is $[-0.5,0]$. Furthermore, he gives a theorem, which is important regarding the overestimation problem.

Theorem 1. Let a continuous function $f: D \subset \mathbb{R}^{n} \rightarrow \mathbb{R}$ be given by an expression $f(x)$ in which each variable $x_{i}, i=1, \ldots, n$, occurs at most once. Then $f(\mathbf{x})=\operatorname{im}(f, \mathbf{x}) \quad \forall \mathbf{x} \subseteq D$.

The image $\operatorname{im}(\cdot)$ should be understood as $\operatorname{im}(f, \mathbf{x})=[f(\underline{\mathbf{x}}), f(\overline{\mathbf{x}})]$. Alefeld and Mayer [1] draw attention to the fact that if variable $x$ occurs in the expression more than once, then $\operatorname{im}(f, \mathbf{x}) \subseteq f(\mathbf{x})$ . In the presented example, $\operatorname{im}(f, \mathbf{x})=[0,0]$. Muhanna, Mullen, et al. [37] write that if in a system of linear equations the same interval parameters occur repeatedly, then in a standard evaluation process they are automatically treated as independent variables, which leads to overestimation. Therefore, researchers aspire to develop a method for finding an optimal interval solution. Shary [53] 
defines the latter as a vector of the shortest possible length which contains the unified solution set of the given interval linear algebraic system.

The interval finite element method (IFEM) concept appears for the first time in [9] for beams with an uncertain stiffness calculation. Muhanna, Mullen, et al. [37], through the use of truss and frame examples, criticize an approach known as naive IFEM and, at the same time, underline the overestimation problem. Naive IFEM relies on a simple replacement of corresponding variables by intervals and on obtaining unknowns through standard FEM calculations. The authors propose the use of an element-by-element approach (EBE) [49, 68] claiming that it eliminates most overestimation sources. They also use Lagrange multipliers (to ensure compatibility conditions and eliminate stiffness matrix singularity caused by EBE) and the M反 method proposed in [38]. Corliss, Foley, et al. [11] use EBE, symbolic rearrangement, a scaling of equations, and constraint propagation to get tight enclosures of the solution of a frame with large uncertainties [61]. Xiao, Muhanna, et al. [64], with the use of Lagrange multipliers and the $\mathbf{M} \boldsymbol{\delta}$ method connected with the iterative enclosure method [40], define an interval Euler-Bernouilli beam finite element. Their main goal is to collect individual interval parameters and delay interval operations.

The work of Neumaier and Pownuk [40] is important from the point of view of solving linear systems. The authors introduce an iterative method for obtaining solution estimations of linear systems in the form $(K+B D A) u=a+F b$, where $K, B, A, F$ are matrices, $u, a, b$ are vectors, $D$ is a diagonal or block-diagonal matrix, and the interval numbers are included only in $D$ and $b$.

\section{FUZZY SETS}

The fuzzy set concept was introduced by Zadeh [67]. Fuzzy set $G$ in space $X$ is a set of ordered pairs $G=\left\{\left(x, \mu_{G}(x)\right), x \in X\right\}: 0 \leqslant \mu_{G}(x) \leqslant 1$ called fuzzy numbers. In contrary to crisp (classical) sets, in which elements either belong to the set or not, the elements' membership to a fuzzy set is described through membership function $\mu_{G}(x)=[0,1]$. In other words, an element can be a set member in some part. The most used membership functions are those of triangular, trapezoidal, or bell (eg. Gauss) distributions [12]. Generally, in numerical applications, fuzzy numbers are reduced to intervals by presentation in terms of $\alpha$-cuts and are defined as $G_{\alpha}=\left\{x \in X, \mu_{G}(x) \geqslant \alpha\right\}$ (see Fig. 8) [50].

Ross [52] writes that fuzzy systems are useful in two situations: when simulated systems are very complicated and are not fully studied or understood, or when the approximated but rapidly obtained 
result is sufficient. Similarly, Niczyj [41] claims that this fuzzy description allows for an estimate of the risk of existing structures in cases of insufficient data sets.

In $[36,38,39,56]$ the authors introduce fuzzy finite elements whose construction is based on interval arithmetic. Using $\alpha$-cuts they obtain intervals of confidence at multiple levels of presumption. The calculations are illustrated with examples of a two-bar truss, a three-span beam, and a plate with a circular hole [36].

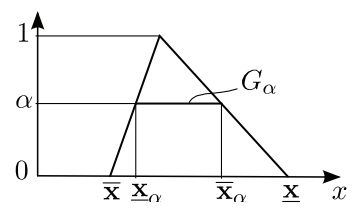

Fig. 8. Fuzzy number for a triangular distribution of membership function and the interval representation $G_{\alpha}$

\section{CONVEX SETS}

In the 1990s Ben-Haim and Elishakoff [5] proposed a new method for analysis of uncertainty. Their method is based on the use of convex models. Qiu and Elishakoff [47] and Ben-Haim [3] specify four convex models used frequently in convex modelling: instantaneous energy-bound, cumulative energy-bound, envelope-bound, and ellipsoidal-bound. Qiu and Elishakoff [47] consider a finite element model with uncertain parameters in stiffness matrix $K$ and load vector $P$. The authors search for the bounds of the solution set, given by

$$
\left\{u: K(p) u=P(p), p \in\left\{p: \sum_{i=1}^{m} \frac{\left(p_{i}-\mathbf{p}_{i}^{c}\right)^{2}}{\Delta \mathbf{p}_{i}^{2}} \leqslant \alpha^{2}\right\}\right\}
$$

where $p$ is the uncertain parameter, $\mathbf{p}^{c}=\left(\mathbf{p}_{i}^{c}\right)$ is the nominal value vector of parameter $p$, $\Delta \mathbf{p}=\left(\Delta \mathbf{p}_{i}\right)$ is the semi-axis vector, and $\alpha$ is the radius of the set. The assumption of an elliptic set of uncertain parameters appears in many other papers $[15,26,45,46]$.

The use of properties of convex sets ${ }^{2}$ in the analysis of uncertainty can be justified by an essential theorem cited by Ben-Haim [4] and given in [5]:

${ }^{2}$ Set $S$ is convex if for all elements $f, g \in S$ and all $0<\alpha<1$ value $\alpha f+(1-\alpha) g$ also belongs to $S$. 
Theorem 2. Let $f(t)$ be a time-or-space-varying uncertain vector function, and let $\Gamma$ be a set of such functions. For a positive integer $n$, consider the set of functions constructed as $n$-fold averages of elements $\Gamma$ :

$$
F_{n}=\left\{f: f(t)=\frac{1}{n} \sum_{m=1}^{n} g_{m}(t), \quad \forall g_{m} \in \Gamma\right\}
$$

It is well known that, as $n \rightarrow \infty$, the sequences of sets $F_{n}, n=1,2, \ldots$ converge to the convex hull of $\Gamma: \lim _{n \rightarrow \infty} F_{n}=\operatorname{ch}(\Gamma)$.

Ben-Haim gives a physical interpretation of the above-mentioned theorem: if process $f(t)$ can be defined as a linear superposition of processes $g_{m}(t)$ taken from set $\Gamma$, then the set of all processes $f(t)$ will be convex, regardless of the structure of $\Gamma$.

Ben-Haim [4] presents examples of engineering analysis based on the studies of convex sets. Among them, the buckling of thin-walled shells with an uncertain shape (or uncertain imperfection) is mentioned. An infinite set of functions which defines the uncertain geometry is possible to formulate. Each function describes a specific shape and the set defines the uncertainty of the shape's occurrence. The set is convex. Similarly, through the use of global properties of seismic events (e.g. total seismic energy), the convex model can be defined as a set of all seismic events consistent with given data. In papers $[22,23]$ a simple method of the interpretation of results obtained from the solution of truss equations with uncertain bar stiffness is presented. The authors propose a description of the displacement solution set as transferred to the space of loads. The method is based on the interpretation of a classical truss system of equations through the use of the Minkowski sum. In [43] the authors describe the truss solution set via a system of inequalities. Both methods lead to convex solution sets.

\section{NUMERICAL EXAMPLE}

The above-mentioned considerations can be illustrated by the following example, proposed in [37]. A two-stepped cantilever is axially loaded with force $P=1$ (see. Fig. 9). The structure consists of two bars of stiffness $k_{1}$ and $k_{2}$, respectively. The Finite Element Method equation system, needed for the displacement set calculation, is in the form 


$$
K q=P, \quad K=\left(\begin{array}{cc}
k_{1}+k_{2} & -k_{2} \\
-k_{2} & k_{2}
\end{array}\right), \quad q=\left(\begin{array}{l}
q_{1} \\
q_{2}
\end{array}\right), \quad P=\left(\begin{array}{l}
0 \\
1
\end{array}\right),
$$

where $u_{1}$ and $u_{2}$ are the axial displacements of nodes 2 and 3 , respectively (see. Fig. 9). The solution set can be expressed in the form

$$
\boldsymbol{\Xi}=\left\{q \in \mathrm{R}^{2} \mid(\exists K \in \mathbf{K})(K q=P)\right\} .
$$

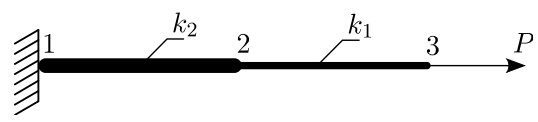

Fig. 9. Two-stepped cantilever loaded axially with force $P$.

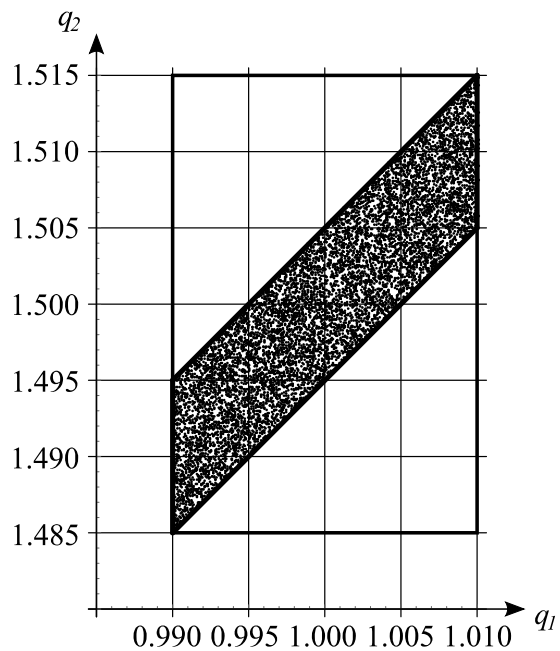

Fig. 10. Solution sets obtained through: interval analysis, shortly called IS (dashed line) [37]; convex methods, CS (solid line); Monte-Carlo method, PS (dots).

It can be assumed that the stiffness belongs to intervals $k_{1} \in \mathbf{k}_{1}=[0.99,1.01]$ and $k_{2} \in \mathbf{k}_{2}=[1.98,2.02]$. The exact solution (interval solution - IS), from the point of view of interval methods, was given by Muhanna, Mullen, et al. [37] in the form 


$$
\mathbf{u}_{1}=\frac{1}{\mathbf{k}_{1}}=[0.990,1.010], \quad \mathbf{u}_{2}=\frac{1}{\mathbf{k}_{1}}+\frac{1}{\mathbf{k}_{2}}=[1.485,1.525]
$$

and was obtained by symbolic transformations. The solution can be presented as a rectangular area in space $q_{1}-q_{2}$ (dashed line in Fig. 10).

The Monte-Carlo method was used to obtain an example of a probabilistic solution (probabilistic solution - PS). The values of $\mathrm{k}_{1}$ and $\mathrm{k}_{2}$ were drawn from intervals $\mathbf{k}_{1}, \mathbf{k}_{2}$ with the assumption of uniform probability distribution. Then, for the given random matrix $K$, the system of equations Eq. (6.1) was solved. The obtained cloud of ten thousand points in space $q_{1}-q_{2}$ is presented in Fig. 10 . In [43], the possibility of the solution set description through the use of an inequalities system and the properties of convex sets is shown. The presented method assumes that $q \in \mathbf{\Xi} \Leftrightarrow\langle u, P\rangle \leq h\left(u, \mathcal{V}_{q}\right) \forall u \in \mathcal{H}$, where $\mathcal{H}$ is a properly chosen finite set of vectors and $h\left(u, \mathcal{V}_{q}\right)$ is the support function. An application of the method for the present example gives the system (convex solution $-\mathrm{CS}$ )

$$
\left|1-q_{1}\right| \leqslant 0.01\left|q_{1}\right|, \quad\left|1+2 q_{1}-2 q_{2}\right| \leqslant 0.02\left|q_{1}-q_{2}\right|,
$$

which in space $q_{1}-q_{2}$ describes a parallelogram (solid line in Fig. 10). The obtained figure bounds the Monte-Carlo solution and is inscribed in the solution of interval analysis. This means that solutions obtained with the convex and probabilistic methods are more accurate than the interval solution - the IS set contains both CS and PS sets. Furthermore, the bounds of the PS and CS sets overlap, but the latter is much less time-consuming.

\section{SUMMARY AND CONCLUSIONS}

Uncertainty in engineering structures can be encountered at every step. Starting with the most obvious - wind or snow loads, whose values and direction of action change over time, through the inaccuracy of the execution of structural elements, to the heterogeneity of the material microstructure. All of the uncertainties mentioned within this paper affect structure behaviour and safety to a greater or lesser extent. It is significant that a large variety of uncertainties implies a variety of methods which allows them to be included in the calculation. 
It is worth noting that interval methods are characterized by relatively high computational speed, but are prone to errors resulting from an overestimation of the results. Unlike the stochastic methods, interval analysis requires less data; instead of information about the probability distribution, it is enough to know the bounds of the parameters (boxes). On the other hand, stochastic methods, like the Monte-Carlo method, allow us to obtain accurate solutions, but are time-consuming and largely dependent on the capabilities of computer hardware.

The next group of methods which allows the introduction of uncertainties are those based on fuzzy sets. Due to their specificity, fuzzy numbers are most often reduced in further analysis to intervals obtained by $\alpha$-cuts. Therefore, the methods are characterized by similar computational speed and accuracy of results. The additional advantage of fuzzy sets is the ability to describe phenomena which are hard to grasp mathematically (for example "little", "much", or "high").

In some cases (as presented in section 6), methods based on convex sets allow us to obtain an accuracy of results similar to stochastic models while maintaining the computational speed characteristic for interval methods. In addition, convex methods allow for the construction of models other than those based on boxes.

\section{REFERENCES}

1. G. Alefeld, G. Mayer, "Interval analysis: Theory and applications", J Comput Appl Math, 121(1):421-464, 2000.

2. T. M. Allen, A. S. Nowak, R. J. Bathurst, "Calibration to determine load and resistance factors for geotechnical and structural design”, Transportation Research E-Circular, (E-C079) 2005.

3. Y. Ben-Haim, "A non-probabilistic measure of reliability of linear systems based on expansion of convex models", Struct Saf, 17(2):91-109, 1995.

4. Y. Ben-Haim, "Convex models of uncertainty: applications and implications", Erkenntnis, 41(2):139-156, 1994.

5. Y. Ben-Haim, I. Elishakoff, "Convex models of uncertainty in applied mechanics”, Elsevier, 1990.

6. J. M. Bernardo and A. F. Smith, Bayesian theory, 2001.

7. P. Bocchini, G. Deodatis, "Critical review and latest developments of a class of simulation algorithms for strongly non-Gaussian random fields", Probabilist Eng Mech, 23(4):393-407, 2008.

8. B. Cambou, "Application of first-order uncertainty analysis in the finite element method in linear elasticity", Proc. 2nd Int. Conf. on Applications of Statistics and Probability in Soil and Structural Engrg, 1975, 67-87.

9. S.-H. Chen, X.-W. Yang, "Interval finite element method for beam structures", Finite Elem Anal Des, 34(1):75$88,2000$.

10. L. F. Contreras, E. T. Brown, M. Ruest, "Bayesian data analysis to quantify the uncertainty of intact rock strength", Journal of Rock Mechanics and Geotechnical Engineering, 10(1):11-31, 2018.

11. G. Corliss, C. Foley, R. B. Kearfott, "Formulation for reliable analysis of structural frames", Reliable Computing, 13(2):125-147, 2007.

12. W. De Mulder, D. Moens, D. Vandepitte, "Modeling uncertainty in the context of finite element models with distance-based interpolation", Proceedings of the 1st International Symposium on Uncertainty Quantification and Stochastic Modeling, 2012.

13. O. Dessombz et al., "Analysis of mechanical systems using interval computations applied to finite element methods", J Sound Vib, 239(5):949-968, 2001.

14. I. Ekeland, "Mathematics and the Unexpected", The University of Chicago Press, 1990.

15. I. Elishakoff, "Essay on uncertainties in elastic and viscoelastic structures: From A. M. Freudenthal's criticisms to modern convex modeling", Comp Struct, 56(6):871-895, 1995. 
16. I. Elishakoff, "Some Questions in Eigenvalue Problems in Engineering", Numerical Treatment of Eigenvalue Problems Vol. 5 / Numerische Behandlung von Eigenwertaufgaben Band 5: Workshop in Oberwolfach, ed. by J. Albrecht et al., Basel: Birkhauser Basel, pp. 71-107, 1991.

17. I. Elishakoff et al., "How to find the range of eigenvalues due to uncertain elastic modulus and mass density?", Whys and Hows in Uncertainty Modelling: Probability, Fuzziness and Anti-Optimization, ed. by I. Elishakoff, Springer-Verlag Wien, pp. 341-355, 1999.

18. EN 1990, "Eurocode - Basis of structural design.”, European Committee for Standardization, 1:1-116, 2004.

19. EN 1995-1-1, "Eurocode 5: Design of Timber Structures - Part 1-1: General - Common Rules and Rules for Buildings.”, European Committee for Standardization, 1:1-121, 2008.

20. R. G. Ghanem, "Hybrid stochastic finite elements and generalized Monte Carlo simulation", J Appl Mech (ASME), 65(4):1004-1009, 1998.

21. R. G. Ghanem, P. D. Spanos, "Stochastic Finite Elements: A Spectral Approach", New York, NY, USA: Springer-Verlag New York, Inc., 1991.

22. W. Gilewski et al., "Truss Structures with Uncertain Parameters - Geometrical Interpretation of the Solution based on Properties of Convex Sets", Procedia Engineering, 111:249-253, 2015.

23. W. Gilewski et al., "Truss structures with uncertain parameters - geometrical interpretation of the solution based on properties of convex sets", Theoretical Foundations of Civil Engineering Vol. 7: Structural Mechanics, ed. by S. Jemioło and M. Gajewski, Warszawa: Warsaw University of Technology Publisher House, pp. 41-52, 2016.

24. T. Hickey, Q. Ju, M. H. Van Emden, "Interval arithmetic: From principles to implementation", J ACM, 48(5):1038-1068, 2001.

25. Y. H. Huang, "Pavement Analysis and Design”, Pearson Education, Inc., 2012.

26. Z. Kang, Y. Luo, A. Li, "On non-probabilistic reliability-based design optimization of structures with uncertainbut-bounded parameters", Struct Saf, 33(3):196-205, 2011.

27. R. B. Kearfott, "Interval Computations: Introduction, Uses, and Resources”, Euromath Bulletin, 2(1):95-112, 1996.

28. N. D. Lagaros, G. Stefanou, M. Papadrakakis, "An enhanced hybrid method for the simulation of highly skewed non-Gaussian stochastic fields", Comput Methods Appl Mech Eng, 194(45):4824-4844, 2005.

29. M. Litwin, M. Górecki, "Assembly mistakes of steel structures (in Polish)”, Budownictwo i Architektura, 4:6372, 2009.

30. W. K. Liu, A. Mani, T. Belytschko, "Finite element methods in probabilistic mechanics", Probabilist Eng Mech, 2(4):201-213, 1987.

31. J. E. Lundberg, T. V. Galambos, "Load and resistance factor design of composite columns", Struct Saf, 18(2):169-177, 1996.

32. P. Mackiewicz, "Fatigue life of asphalt mixtures used in pavements (in Polish)", Oficyna Wydawnicza Politechniki Wrocławskiej, 2016.

33. D. Moens, D. Vandepitte, "A survey of non-probabilistic uncertainty treatment in finite element analysis", Comput Methods Appl Mech Eng, 194(12):1527-1555, 2005.

34. R. Moore, W. Lodwick, "Interval analysis and fuzzy set theory", Fuzzy Set Syst, 135(1):5- 9, 2003.

35. R. E. Moore, "Interval arithmetic and automatic error analysis in digital computing", $\mathrm{PhD}$ thesis, Stanford University, 1962.

36. R. L. Muhanna, R. L. Mullen, "Formulation of Fuzzy Finite-Element Methods for Solid Mechanics Problems", Computer-Aided Civ Inf, 14(2):107-117, 1999.

37. R. L. Muhanna, R. L. Mullen, H. Zhang, "Interval finite elements as a basis for generalized models of uncertainty in engineering mechanics", Reliable Computing, 13(2):173-194, 2007.

38. R. L. Mullen, R. L. Muhanna, "Bounds of structural response for all possible loading combinations", J Struct Eng, 125(1):98-106, 1999.

39. R. L. Mullen, R. L. Muhanna, "Structural analysis with fuzzy-based load uncertainty", Probabilistic Mechanics \& Structural Reliability, ASCE, 310-313, 1996.

40. A. Neumaier, A. Pownuk, "Linear systems with large uncertainties, with applications to truss structures", Reliable Computing, 13(2):149-172, 2007.

41. J. Niczyj, "Multi-criterion reliability optimization and technical assessment of bar structures on the background of fuzzy set theory (in Polish)", Polish, Szczecin Univ. of Technology Publishers, Nr 581 (3):3-229, 2003.

42. M. Papadrakakis, V. Papadopoulos, "Robust and efficient methods for stochastic finite element analysis using Monte Carlo simulation”, Comput Methods Appl Mech Eng, 134(3):325-340, 1996.

43. J. Pełczyński, T. Rzeżuchowski, J. Wąsowski, "Description of united solution sets by in-equalities for truss structures", 4th ECCOMAS Young Investigators Conference (YIC 2017), 2017.

44. K. Phoon, H. Huang, and S. Quek, "Simulation of strongly non-Gaussian processes using Karhunen-Loeve expansion”, Probabilist Eng Mech, 20(2):188-198, 2005. 
45. Z. Qiu, "Comparison of static response of structures using convex models and interval analysis method", Int J Numer Meth Eng, 56(12):1735-1753, 2003.

46. Z. Qiu, "Convex models and interval analysis method to predict the eff ect of uncertain-but-bounded parameters on the buckling of composite structures", Comput Methods Appl Mech Eng, 194(18):2175-2189, 2005.

47. Z. Qiu and I. Elishakoff, "Anti-optimization technique - A generalization of interval analysis for nonprobabilistic treatment of uncertainty", Chaos, Solitons and Fractals, 12(9):1747- 1759, 2001.

48. U Radoń, "Reliability analysis of Mises truss", Arch Civ Mech Eng, 11(3):723-738, 2011.

49. M. V. R. Rao, R. L. Muhanna, R. L. Mullen, "Interval Finite Element Analysis of Thin Plates", 7th International Workshop on Reliable Engineering Computing, 2016, 111-130.

50. S. S. Rao, L. Chen, "Numerical solution of fuzzy linear equations in engineering analysis", Int J Numer Meth Eng, 43(3):391-408, 1998.

51. R. J. Ross, ed., "Wood handbook - wood as an engineering material. General Technical Report FPL-GTR-190", U.S. Department of Agriculture, Forest Service, Forest Products Laboratory, 2010.

52. T. J. Ross, "Fuzzy logic with engineering applications", John Wiley \& Sons, 2004.

53. S. P. Shary, "On optimal solution of interval linear equations", SIAM J Numer Anal, 32(2):610-630, 1995.

54. M. Shinozuka, G. Deodatis, "Response Variability Of Stochastic Finite Element Sys-tems", J Eng Mech, 114(3):499-519, 1988.

55. A Simoneau, E Ng, M. A. Elbestawi, "Chip formation during microscale cutting of a medium carbon steel”, Int J Mach Tool Manu, 46(5):467-481, 2006.

56. J Skrzypczyk, "Fuzzy methods in the analysis of uncertain systems", Zeszyty Naukowe. Budownictwo/Politechnika Śląska, (86):183-196, 1999.

57. A. P. Smith, J. Garloff, H. Werkle, "Verified solution for a simple truss structure with uncertain node locations", Proceedings of the 18th International Conference on the Application of Computer Science and Mathematics in Architecture and Civil Engineering, Weimar, Germany, 2009.

58. E Sobczyńska, W Wasilewski, M Gregoriou-Szczepaniak, "Issues of modeling of masonry structures: case study of tenement house at Szara street in Warsaw (in Polish)", Journal of Civil Engineering, Environment and Architecture, 63(4):607-615, 2016.

59. P. D. Spanos, R. Ghanem, "Stochastic finite element expansion for random media", J Eng Mech, 115(5):10351053, 1989.

60. G. Stefanou, "The stochastic finite element method: Past, present and future", Comput Methods Appl Mech Eng, 198(9-12):1031-1051, 2009.

61. P. Van Hentenryck, L. Michel, and Y. Deville, "Numerical: a modeling language for global optimization", MIT Press, 1997.

62. E. Vanmarcke, M. Grigoriu, "Stochastic finite element analysis of simple beams", J Eng Mech, 109(5):1203$1214,1983$.

63. P. Wojnarowski, "Hydrocarbons reserves estimation for fields in early stage of development with application of interval analysis (in Polish)", Wiertnictwo, Nafta, Gaz, 27:781-787, 2010.

64. N. Xiao et al., "Interval finite elements for uncertainty in frame structures", 11th International Conference on Structural Safety \& Reliability, pp. 16-20, 2013.

65. F. Yamazaki et al., "Neumann expansion for stochastic finite element analysis", J Eng Mech, 114(8):1335-1354, 1988.

66. K.-V. Yuen, "Bayesian methods for structural dynamics and civil engineering", John Wiley \& Sons, 2010.

67. L. A. Zadeh, "Fuzzy sets", Information and Control, 8(3):338-353, 1965.

68. H. Zhang, "Nondeterministic linear static finite element analysis: an interval approach", $\mathrm{PhD}$ thesis, Georgia Institute of Technology, 2005. 


\section{LIST OF FIGURES AND TABLES:}

Fig. 1. Non-uniformly distributed aggregates in asphalt mixture. One can see a significant difference between the left and right side of the figure. From the author's own collections.

Rys. 1. Nierównomiernie rozłożone składniki mieszanki bitumicznej. Można zauważyć znaczną różnicę między lewą I prawą stroną rysunku. Ze zbiorów autora.

Fig. 2. Glued laminated timber with gaps and knots. From the author's own collections.

Rys. 2. Drewno klejone warstwowo z widocznymi szczelinami i sękami.

Fig. 3. Microstructure of steel [55].

Rys. 3.Mikrostruktura stali [55].

Fig. 4. Overextended strut due to improper prestress [29].

Rys. 4. Zbyt długie cięgno ze względu na złe naciągnięcie [29].

Fig. 5. Some possible uncertain parameters in truss.

Rys. 5. Możliwe parametry niepewne w kratownicy.

Fig. 6. Possibility distribution of $x$ lying in interval $[\underline{\mathbf{x}}, \overline{\mathbf{x}}]$.

Rys. 6. Rozkład prawdopodobieństwa $x$ znajdującego się w przedziale $[\underline{\mathbf{x}}, \overline{\mathbf{x}}]$.

Fig. 7. Interval $[\underline{\mathbf{x}}, \overline{\mathbf{x}}]$.

Rys. 7. Przedział $[\underline{\mathbf{x}}, \overline{\mathbf{x}}]$.

Fig. 8. Fuzzy number for a triangular distribution of membership function and the interval representation $G_{\alpha}$

Rys. 8. Liczba rozmyta dla trójkątnego rozkładu funkcji przynależności oraz reprezentacja przedziałowa $G_{\alpha}$ Fig. 9. Two-stepped cantilever loaded axially with force P.

Rys. 9. Dwuelementowy wspornik obciążony osiowo siłą $P$.

Fig. 10. Solution sets obtained through: interval analysis, shortly called IS (dashed line) [37]; convex methods, CS (solid line); Monte-Carlo method, PS (dots).

Rys. 10. Zbiory rozwiązań otrzymane za pomocą: analizy przedziałowej, skrótowo IS (linia przerywana)

[37]; zbiorów wypukłych, CS (linia ciągła); metody Monte-Carlo, PS (linia kropkowana). 


\section{O MATEMATYCZNYM OPISIE PARAMETRÓW NIEPEWNYCH W KONSTRUKCJACH INŻYNIERSKICH}

Słowa kluczowe: niepewność, zbiór wypukły, przedział, prawdopodobieństwo, zbiór rozmyty

\section{Podsumowanie:}

W dzisiejszych czasach automatyzacja procesu produkcyjnego ma bardzo duży wpływ na bardzo duży wpływ na jakość oraz precyzję wykonania elementów konstrukcyjnych. Jednakże nie jest możliwe całkowite wyeliminowanie niepewności występujących w zagadnieniach inżynierskich. Materiały występujące w budownictwie nie są jednorodne, choć na pierwszy rzut oka mogą za takowe uchodzić, a kryterium jednorodności jest jednym z podstawowych założeń podczas projektowania. Na własności mechaniczne materiałów, takich jak mieszanka bitumiczna, bardzo duży wpływ ma jej temperatura. W drewnie, zarówno litym jak i klejonym warstwowo, występują spękania, sęki czy zakorki, które mają bardzo duży wpływ na lokalne własności mechaniczne materiału. Również wilgotność może znacznie zmienić ciężar czy wytrzymałość elementu drewnianego. Elementy stalowe natomiast podlegają korozji, która z czasem może zmienić wymiary elementu.

Duże zróżnicowanie parametrów niepewnych występujących w budownictwie powoduje różnorodność metod pozwalających na ich uwzględnianie. W światowej literaturze można znaleźć wiele publikacji traktujących o sposobach opisu niepewności. Najbardziej popularne są metody oparte na procesach stochastycznych, arytmetyce przedziałowej, zbiorach rozmytych oraz zbiorach wypukłych. Można wyszczególnić również publikacje przedstawiające podejścia mieszane. W metodach probabilistycznych, wśród których najbardziej popularną jest metoda Monte-Carlo, parametry niepewne traktowane są jako zmienne losowe. Metody przedziałowe bazują na analizie przedziałowej. Zakładają, że parametr niepewny jest nieznany, ale ograniczony z góry oraz z dołu i znane są jego granice. Uogólnieniem przedziałów są zbiory rozmyte. Pozwalają na określenie w jakim stopniu dany parametr należy do określonego zbioru. Analiza wypukła bazuje na założeniu, że niektóre procesy można opisać za pomocą zbiorów wypukłych. Niniejsza praca przedstawia opisz wymienionych metod, ich podstawowe wady i zalety oraz najbardziej popularne miejsca zastosowania. Omówione metody przedstawione są za pomocą przykładu wspornika o skokowo zmiennym przekroju, obciążonego osiowo siłą rozciągającą. Pokazane jest porównanie wyników otrzymanych metodą Monte-Carlo, metodą przedziałową oraz z wykorzystaniem układu nierówności otrzymanego za pomocą analizy wypukłej.

Podstawowe wnioski są następujące: metody przedziałowe charakteryzują się względnie dużą szybkością obliczeń, ale podatne są na błędy wynikające z przeszacowań wyników. Metody probabilistyczne wymagają więcej danych do budowy modelu obliczeniowego, są wolniejsze, jednak pozwalają na otrzymanie dokładnych wyników, często wykorzystywanych do weryfikacji innych metod. Podstawową zaletą metod opartych na zbiorach rozmytych jest możliwość opisania pojęć trudnych do ujęcia matematycznego, takich jak „mało”, „dużo” czy „,wysoki”. W pewnych przypadkach, na przykład dla konstrukcji kratowych, metody oparte na zbiorach wypukłych pozwalają na otrzymanie dokładnych zbiorów rozwiązań konstrukcji o niepewnych parametrach. 